\title{
The Role of Media on Knowledge, Awareness and Students' Attitude during Movement Control Order (MCO)
}

\author{
Noreen Noor Abd Aziz¹, Juliana Mohd Abdul Kadir1, Nadia Nurul Najwa Mohmad Hassan", \\ Nor Balkish Zakaria², Gancar Candra Premananto ${ }^{3}$ \\ 1 Faculty of Business Management, Universiti Teknologi MARA Johor, Malaysia \\ ${ }^{2}$ Accounting Research Institute, Universiti Teknologi MARA, Malaysia \\ ${ }^{3}$ Faculty of Economy and Business, Universitas Airlangga, Indonesia
}

noree974@uitm.edu.my, julia593@uitm.edu.my, nadia666@uitm.edu.my,norbalkish@uitm.edu.my, gancar-c-p@feb.unair.ac.id Tel:+6019-777 7217

\begin{abstract}
The Malaysian government had announced the Movement Control Order (MCO) to handle the Covid-19 crisis. During MCO, the government has used media channels to spread the information to the public. This research aims to identify the mediating part of both knowledge and awareness between students' attitude and media role during MCO. The findings from 338 respondents analysed using structural equation modelling found that knowledge and awareness mediate between media and students' attitude. This study could guide policymakers to promote a greater understanding of the coronavirus pandemic by using the mass media.
\end{abstract}

Keywords: Knowledge, Awareness, Attitude, Role of Media

eISSN: 2398-42870 2021. The Authors. Published for AMER ABRA CE-Bs by e-International Publishing House, Ltd., UK. This is an open access article under the CC BYNC-ND license (http://creativecommons.org/licenses/by-nc-nd/4.0/). Peer-review under responsibility of AMER (Association of Malaysian Environment-Behaviour Researchers), ABRA (Association of Behavioural Researchers on Asians/Africans/Arabians) and cE-Bs (Centre for Environment-Behaviour Studies), Faculty of Architecture, Planning \& Surveying, Universiti Teknologi MARA, Malaysia.

DOI: https://doi.org/10.21834/ebpj.v6i16.2712

\subsection{Introduction}

Covid-19 outbreaks are widespread among people in Asia and became pandemic in the world. This phenomenon erupted in China and became a global health crisis with no stopping sign. Excessive activity causes many people to become infected with the virus transmitted. Consequently, the government has taken drastic steps to monitor most activities to control the virus's spread quickly. The government has strategies for the public for self-isolated and encourage people to stay healthy by using masks and sanitisers for infectious viruses and help protect older people and those with underlying health problems from getting infected. By $18^{\text {th }}$ March 2020 , the Malaysian government has announced the Movement Control Order (MCO) for Malaysia for two weeks and continue for phase two and three. People should stay at home and practice social distancing when visiting places for necessity purposes.

During MCO, the government uses a media channel to spread the information to the public. The Malaysian government uses the media to pass the information on the pandemic updates such as the policies and standard operating procedures via the Ministry of Health Malaysia (MOH) and the National Security Council (MKN). Malaysian government agencies such as the National Security Council (MKN) utilises the Telegram application to disseminate the latest and authentic information on the Covid-19 case in Malaysia. The

eISSN: 2398-4287C 2021. The Authors. Published for AMER ABRA cE-Bs by e-International Publishing House, Ltd., UK. This is an open access article under the CC BYNC-ND license (http://creativecommons.org/licenses/by-nc-nd/4.0/). Peer-review under responsibility of AMER (Association of Malaysian Environment-Behaviour Researchers), ABRA (Association of Behavioural Researchers on Asians/Africans/Arabians) and cE-Bs (Centre for Environment-Behaviour Studies), Faculty of Architecture, Planning \& Surveying, Universiti Teknologi MARA, Malaysia.

DOI: https://doi.org/10.21834/ebpj.v6i16.2712 
Malaysian government has also developed a smartphone application known as MySejahtera to help the community report information on the whereabouts, personal and family health, other than for the related agency to provide information regarding Covid-19 infection.

Necessary health education through mass media such as websites and other online media encourages people to conduct healthrelated behaviour (Sumaedi, Bakti, Rakhmawati, Widianti, Astrini, Damayanti, Massijaya and Jati, 2020). The use of media for information dissemination and communication should be controlled and monitored. The transmission of inaccurate information and fake news is seen as a serious problem threatening the country's peace and security. The Communications and Multimedia Commission of Malaysia Act (1998) and the Communications and Multimedia Act (1998) are developed to ensure that the act can control inaccurate information and transmit false news. The government should promote the official Covid-19 website as the primary source of information regarding Covid-19. The citizen should validate the information from specific sources with the website's information (Sumaedi et al., 2020).

\subsection{Problem Statement}

The World Health Organization (WHO) and the Center for Disease Control and Prevention (CDC) have developed measures as guidelines for policymakers and the public to take actions in the diseased outbreak. During MCO, people need to stay at home and avoid mass gatherings to reduce infection risk. However, some cases and challenges need to be resolved because people do not obey the government's order. In the second phase of the MCO, there were 14,922 cases issued by the police for those opposing the MCO. These cases are increasing, and the government has taken drastic steps and implemented RM1000 worth of compound action against those who oppose the regulation.

Notwithstanding the government's many media types to warn the citizen, some did not adhere to the government's standard operating procedures. Sumaedi et al. (October 2020) stressed that the "Stay at Home" policy threatens income source, causing people to prioritise financial threats over COVID-19. People opted to defy the procedure because the danger of COVID-19 was not convincing enough compared to hunger and poverty. The media plays a role in disseminating news and information by the government. Some of the info misinterpreted or falsified may influence people's attitude towards the disease as stated by Sumaedi et al. (October 2020) that the misinformation among Indonesian published through social media has degraded the level of danger Covid-19 posed.

Public attention to correct and conscious online behaviour, especially during the pandemic burden, is crucial to avoid the negative consequence of social media use (Brailovskaia, Cosci, Mansueto and Margraf, 2021). Naeem (2020) emphasised that there should be communication from credible sources regarding how people can handle the health crisis. A study by Casais and Proenca (2020) found that social marketing regarding HIVIAIDS prevention advertisements on television is provided by governments rather than by nongovernment organisation. Social advertising should reflect the policy, socio-economic and cultural context of the country where it is implemented.

Students attitude toward disease prevention is essential to ensure they and their families are free from infectious diseases. Therefore, this study examines the media's role in providing knowledge and awareness to students. The students' increased knowledge and awareness may have affected their attitude towards overcoming Covid-19 infection. Therefore, a better understanding of the role of today's media and the attitude towards pandemics Covid-19 is crucial to influence adherence to government regulations. Hence, a study should be conducted to determine the mediating effect of awareness and knowledge between the role of media and students' attitudes during MCO to stop the spread of Covid-19.

\subsection{Objectives of Study}

The mass media might play a significant role in raising students' awareness and knowledge of the disease. Apart from that, media also play a role in influencing students' attitude on their efforts in preventive measures of Covid-19 disease. Therefore, this research aims to identify the mediating part of knowledge between the role of media and students' attitude during MCO. Simultaneously, the second objective is to identify the mediating role of awareness between media and students' attitude during $\mathrm{MCO}$. In principle, understanding students' knowledge, awareness, and attitude during the MCO of Covid-19 pandemic through media in Malaysia is essential in increasing the level of health care awareness and enhancing students' good behaviour toward lifestyle sustainability.

\subsection{Literature Review}

This study integrates the media's role and the mediating effect of knowledge and awareness towards students' attitude. It attempts to extend the Theory of Planned Behavior (TPB), in which attitude is regarded as resulting from knowledge and awareness.

The Role of Media. During the MCO, the mass media played an essential role in disseminating information on Covid-19 disease and reporting government plans and strategies and most of the country's issues. The media can represent and deliver crucial educational information for the community and improve their understanding (Corbett and Durfee, 2004). The other medium to provide news is social media such as Facebook, Twitter, and blogs. It is the most widely used and fast communication tool for disseminating information to a broader community (Hamid et al., 2017; Irwin et al., 2012; Kimmons, 2014).

Sumaedi et al. (2020) found that intention to use official COVID-19 websites is significantly and positively affected by the website's quality, attitude and subjective norm. The study indicated that if someone has a favourable evaluation of the website, they would be more likely to use it. Brailovskaia, Cosci, Mansueto and Margraf (2021), found that most participants frequently used official government 
sites, followed by news reports on television and social media. The printed media were the least used media to get the information on Covid-19.

Knowledge. The previous study reported that those who did not know some information mostly among university's students, such as knowledge about protection from disease, the symptom, and the fatality rate (Almutairi, 2016). Moreover, Zhong, Luo, Li, Zhang, Liu, Li and Li (2020) stated that the knowledge score was associated with a lower likelihood of preventive practices towards Covid-19. Haushofer and Metcalf (2020) found that contagion processes can be used to maximise the spread of protective information and behaviour. Xie, Zang and Ponzoa (2020) found that the Covid-19 information from mainstream Chinese media and overseas had a significant effect on college students' online knowledge acquisition. The result showed that the more positive students' response towards the pandemic situation, the stronger their willingness to obtain such knowledge through online means.

Awareness. In raising awareness of MCO compliance, two perspectives are identified with behavioural change. The first perspective assumes that behavioural change is due to an increase in people's knowledge by raising awareness of a problem and fostering appropriate attitudes. The second perspective proposes that individuals review their choices systematically and then act for their economic benefit without adequate prior knowledge and awareness (McKenzie-Mohr, 2000). Awareness plays a role in shaping an attitude through evaluative conditioning by repeatedly pairing a stimulus with other stimuli of positive or negative valence (Sweldens, Corneille and Yzerbyt, 2014).

Attitude. According to Ajzen and Fishbein (2000), attitude can be described as a tendency to react positively or negatively to a given object. Attitude is important because it influences his intentions and behaviour. There is the question of whether the media can change a person's attitude. Wang, Chen, \& Liang (2011) found a negative attitude towards social media when college students use it. For example, a student spends more than six hours checking social media sites, which could be detrimental to student performance. However, for developing countries, the media's impact is significant on attitudes change (Firouzeh, 2004). Social media use is positively associated with stress symptoms and experience burden (Brailovskaia, Cosci, Mansueto and Margraf, 2021). A study found social media platform features are the significant motivation that influences attitude towards online donation related to Covid-19 response (Nashwan and Daihani, 2020).

\subsection{Methodology}

A convenience sampling technique was selected for this research. This approach is a type of nonprobability sampling and appropriate for research that aims to test the relationships of variables (Sekaran and Bougie, 2010). The respondents chosen are stipulated to the government to stay home during corona disease. An online questionnaire was distributed to operationalise the TPB components to 338 students in UiTM Johor, and it took about a month to complete the data collection. The Likert five-point scale was used for all the 21 questions, which are strongly disagree, disagree, neutral, agree and strongly agree. This research employs structural equation modelling to examine the relationship between the studied variables. Partial least squares (PLS) model analysis was used to evaluate data. Abdul Hafaz Ngah (2014) and Akter, S., D'Ambra, J., \& Ray, P. (2011) indicate that PLS helps evaluate empirical validation and theoretical conceptualisation. The data were analysed using the following steps; first, the model measurement was assessed using confirmatory factor analysis. Secondly, the standard path coefficient and $t$-statistics ( $t>1.96)$ were examined for the structural model measurement.

\subsection{Findings}

\section{Sample Profiles}

Sample profiles revealed that 78.7 per cent of the respondents in this study were primarily female and only 21.3 per cent of the total respondents were male. It claimed that $53.6 \%$ of respondents were 18 and 20 years of age. Besides, 40.2 per cent of respondents were 21-23 years old, reflecting 21-23 years of age. About 5.6 per cent of respondents were between the ages of 24 and 26 . Nonetheless, respondents over 26 years of age contributed to $0.6 \% .49 .4$ per cent reflect bachelor degrees, 50 per cent for diploma and 0.6 per cent for pre-diplomas, depending on the study level.

\section{Measurement Model}

Convergent validity is calculated by measuring the item reliability, internal consistency and average variance extracted (AVE) as suggested by Fornell and Larcker (1981). The loadings for each item are measured by item reliability. The extensive item loadings are presented in Table 1. The loadings display the association with their respective constructs of the objects. The findings suggest that all goods are more significant than 0.7, which can be considered appropriate (Chin, W. W.,2010).

This table also shows that all the AVE values are above 0.5. As Average Variance Extracted (AVE), the most significant value is 0.718 for awareness while the lowest is 0.502 for media role. Hence, Internal Consistency meets the criterion for a minimum value of 0.7. Based on the results after it has been revised, it is found that the lowest internal consistency is 0.752 for the role of media whilst the highest is 0.927 for awareness. The reliability of the measurement model ensures the high internal consistency values for all the constructs. Therefore, the measurement model has satisfied all three necessary criterions and achieved convergent validity. Thus, these results indicate that each construct's items are highly correlated and reliable.

The first criterion validity criteria are assessed by calculating the square root of the average variance extracted (AVE). This value is then compared with the inter construct correlation. To meet the discriminant validity criteria, the AVE's square roots were calculated and represented in the main diagonal of Table 2. The off-diagonal elements represent the correlations among the latent variables. Barclay, 
Higgins, and Thompson (1995) specify that discriminant validity is achieved when the AVE of a construct's square root is more significant than its correlation with other constructs. Table 2 confirms that the discriminant validity has been completed.

Next, the cross-loading matrix explained that all items are loaded higher on the construct they measured than on any other constructs in the model. Therefore, the two criteria of discriminant validity were met. The implication is that all the reflective constructs in the measurement model are different from each other.

\begin{tabular}{|c|c|c|c|c|}
\hline Construct & Item & Loading & AVE & Internal Consistency \\
\hline \multirow[t]{5}{*}{ Attitude } & ATT1 & 0.798 & 0.645 & 0.900 \\
\hline & ATT2 & 0.838 & & \\
\hline & ATT3 & 0.707 & & \\
\hline & ATT4 & 0.866 & & \\
\hline & ATT5 & 0.886 & & \\
\hline \multirow[t]{5}{*}{ Awareness } & AWR1 & 0.896 & 0.718 & 0.927 \\
\hline & AWR2 & 0.749 & & \\
\hline & AWR3 & 0.872 & & \\
\hline & AWR4 & 0.858 & & \\
\hline & AWR5 & 0.853 & & \\
\hline \multirow[t]{5}{*}{ Knowledge } & KNW1 & 0.732 & 0.576 & 0.871 \\
\hline & KNW2 & 0.737 & & \\
\hline & KNW3 & 0.820 & & \\
\hline & KNW4 & 0.802 & & \\
\hline & KNW5 & 0.789 & & \\
\hline \multirow[t]{4}{*}{ Role of Media } & ROM1 & 0.785 & 0.502 & 0.752 \\
\hline & ROM2 & 0.702 & & \\
\hline & ROM3 & 0.812 & & \\
\hline & ROM4 & 0.816 & & \\
\hline
\end{tabular}

Table 2: Discriminant Validity

\begin{tabular}{ccccc}
\hline Construct & Attitude & Awareness & Knowledge & \\
\hline Attitude & 0.803 & & \\
\hline Awareness & 0.664 & 0.847 & & \\
\hline Knowledge & 0.57 & 0.61 & 0.759 & 0.549 \\
\hline Role of Media & 0.531 & 0.516 & 0.610 \\
\hline
\end{tabular}

\section{Result of Hypothesis Testing}

Relationship

Table 3: Bootstrapping

$\begin{array}{llll}\text { Standard Path } & \text { T-statistics } & \text { p-value } & \text { Results } \\ \text { Coefficients } & & & \end{array}$




\begin{tabular}{|c|c|c|c|c|}
\hline $\mathrm{HI}=$ Role of Media $->$ Awareness $->$ Attitude & 0.230 & 5.192 & 0.000 & Supported \\
\hline H2 = Role of Media $->$ Knowledge $>>$ Attitude & 0.104 & 2.354 & 0.019 & Supported \\
\hline
\end{tabular}

Table 3 indicates the bootstrapping for the primary model. The standardised path coefficient indicates whether the relationship's direction is either positive or negative, whilst the t-value assesses whether this relationship is significant or not. $\mathrm{H} 1$ and $\mathrm{H} 2$ examined the influence of, respectively.

This table shows that all two variables for standard path coefficients are positive. More specifically, for $\mathrm{H} 1$, the standardised path coefficient is 0.230 , whilst the $t$-value is 5.192. The result was accepted at $t>1.96$. As for $H 2$, it explained the standard path coefficient is 0.104 whilst the $t$-value is 2.354 . The result was accepted at $t>1.96$. In conclusion, $\mathrm{H} 1$ and $\mathrm{H} 2$ of the hypotheses were statistically significant.

Thus, from the findings, it was found that there is a significant influence on mediating part of both knowledge and awareness between students' attitude and media role during MCO.

\subsection{Discussion}

Knowledge and awareness are essential aspects that can affect people's attitudes, which the media's role has influenced. Students are quickly adapting information they get via the source of mass media. Media nowadays has played a significant role in building people's knowledge and awareness, which indirectly impacted people's attitudes. Past studies show mass media can play an upstanding role in enhancing people knowledge and awareness (Xie, Zang and Ponzoa, 2020).

From the study's findings, it had been proved that knowledge mediated between the role of media and students' attitude. There is a significant relationship between media, knowledge and attitude of students, which had a considerable measure to see either media enhances pandemic knowledge to drive individuals' attitude. In this regards, Delpont et al. (2020) found a significant role of knowledge and attitude; people had practised ways of prevention towards disease when they know (Ahmad, Iram Jabeen, 2020).

Besides, media plays an important role that increases students' awareness and attitude due to information spread through media every day. It helps them understand the news and issues happening in a country and worldwide. This positive relationship between three dimensions of the variables is evident with Firouzeh (2004) and Brailovskaia, Cosci, Mansueto and Margraf, (2021).

\subsection{Conclusion \& Recommendation}

The study examined the effects of knowledge and awareness between media role and students' attitude during MCO in Malaysia. The respondents were selected from UITM Johor students below 26 years, and the survey was conducted in 3 weeks in May 2020. Since March 2020, the Covid-19 cases are rising, causing the government to perform a lockdown or MCO for a country. At that time, most people stayed and worked from home. They are contacted and communicated through media channels and online meetings, whereby physical discussions are avoided. This situation affects their emotions when not socialising with others.

Therefore, the media plays the best role in disseminating information on the disease's adverse effects and specific issues, particularly during Covid-19 MCO. Apart from that, the media is essential in this hardness and struggling time. People obtain information from the media with the convenience of the tools. This action proves that the role of media should not be neglected in channelling news to the public hence increasing students' knowledge and level of awareness of the time of Covid-19 struggle and shaping a positive attitude among students.

Based on statistics results, it found that media positively affects awareness, knowledge, and attitudes. For our young generations, in this pandemic era, it is very effective to raise awareness and knowledge about Covid19 through media since people have to understand the risk and how to deal with the threats. Students know and are aware of the infection, preventive measures, and precautions against the disease. Based on the path coefficient, the media role is higher on building awareness than knowledge; it means that the research gives more supports on research by Malandrino et al. (2013) that awareness can help users of a website to discriminate against harmful activities and then it will inform about the risk that may happen during navigation. This finding is significant for the government to understand media effectiveness to make the public aware of the threat of a pandemic and be mindful of the new pandemic regulations. Therefore, this will decline the graph of the Covid-19.

The TPB model used is appropriate for the focus group, and this study successfully explained the attitude of students in viewing the disease by the role of media. These findings seem to emphasise efforts to encourage young people to adhere to government plans and campaign to reduce the Covid-19 case and reopen the various sectors of the economy that were closed during the MCO. Therefore, more comprehensive measures should be taken. The media's role is crucial to be strengthened by providing excellent and beneficial news to the community by promoting a greater understanding of the coronavirus pandemic.

Nevertheless, it is noteworthy that this study did not include all behavioural factors in the model, such as subjective norms and perceived behavioural control. Based on these limitations, it could be suggested that future research could arrange with different demographic conditions. Unlike demographics, or even geographic and psychographics, could give different perspectives about the role of media. The meaning of this kind of research is valuable to understand consumer profile on segmentation. Besides, this study 
contributes to the existing knowledge in the mass media industry and promotes more understanding of students' behavioural aspects. Engaging students as respondents to Theory of Planned Behaviour, this study highlights how initial knowledge and awareness help enhance media roles to the public during any disaster. It is also suggested that future research focus on different respondent segmentation among diverse generational cohorts to impact this study.

\section{Acknowledgements}

We want to thank the UiTM Johor for the research grant and not forget survey respondents for taking their time to answer the questionnaire and this paper's reviewers for their valuable comments.

\section{Paper Contribution to Related Field of Study}

This research has meaning on social marketing are, in which the government should persuade their people to change attitude or behaviour. And this study gives us information that media has an essential role in changing public awareness, knowledge and attitude toward the deadly pandemic. But they're still so many homework that we could do to have more understanding toward it.

\section{References}

Abdul Hafaz Ngah, Y. Z. (2014). Modelling of Halal Warehouse Adoption Using Partial Least Squares International Journal of Contemporary Business Management 1(1):71-86.

Ahmad, M., Iram, K., \& Jabeen, G. (2020). Perception-based influence factors of intention to adopt COVID-19 epidemic prevention in China. Environmental research, 190, 109995.

Akter, S., D'Ambra, J., \& Ray, P. (2011). Trustworthiness in mHealth information services: an assessment of a hierarchical model with mediating and moderating effects using partial least squares (PLS). Journal of the American Society for Information Science and Technology, 62(1), 100-116.

Almutairi, M. A. (2016). Awareness about Middle East Respiratory Syndrome Corona Virus (MERS-CoV) Among Dental Students in Riyadh, Saudi Arabia. Pakistan Oral and Dental Journal, 36(3), 426-429.

Ajzen, I., \& Fishbein, M. (2000). Attitudes and the attitude-behavior relation: Reasoned and automatic processes. European review of social psychology, 11(1), 1-33.

Barclay, D., Higgins., \& R.Thompson. (1995). The Partial Least Squares (PLS) approach to causal modeling: Personal computer adoption and uses as an illustration. Technology Studies, 7(7), 1-78.

Brailovskaia, J., Cosci, F., Mansueto, G. and Margraf, J. (2021). The Relationship Between Social Media Use, Stress Symptoms and Burden Caused by Coronavirus (Covid-19) In Germany And Italy: A Cross-Sectional and Longitudinal Investigation. Journal of Affective Disorders Reports 3.

Casais, B., Proenca, J. F. (2018). Social Advertisements for Public Health and Epidemic Dynamics: A Study Based On HIVIAIDS Prevention Television Advertisements in Four European Countries. Journal of Social Marketing, 8(4). https://doi-org.ezaccess.library.uitm.edu.my/10.1108/JSOCM-07-2014-0049

Chin, W. W. (2010). How to write up and report PLS analyses. In Handbook of partial least squares (pp. 655-690). Springer, Berlin, Heidelberg.

Corbett, J. B., \& Durfee, J. L. (2004). Testing Public (un) Certainty of Science: Media Representations of Global Warming. Science Communication, 26(2), $129-151$.

Delpont, M., Racicot, M., Durivage, A., Fornili, L., Guerin, J. L., Vaillancourt, J. P., \& Paul, M. C. (2020). Determinants of biosecurity practices in French duck farms after a H5N8 Highly Pathogenic Avian Influenza epidemic: The effect of farmer knowledge, attitudes and personality traits. Transboundary and emerging diseases.

Firouzeh, N. (2004). Globalisation and Homogenisation of Culture: The Role of Mass Media in Developing Countries. Societal Responsibilities in Life Sciences, (12), 235.

Hamid, S., ljab, M. T., Sulaiman, H., Anwar, R. M., \& Norman, A. A. (2017). Social Media for Environmental Sustainability Awareness in Higher Education. International Journal of Sustainability in Higher Education.

Haushofer, J., \& Metcalf, J. E. (2020). Combining Behavioural Economics and Infectious Disease Epidemiology to Mitigate the COVID-19 Outbreak, pp. 1 - 10.

Irwin, C., Ball, L., Desbrow, B. and Leveritt, M. (2012), Students' Perceptions of Using Facebook as an Interactive Learning Resource at University, Australasian Journal of Educational Technology, 28(7), pp.1221-1231.

Kimmons, R. (2014), Social Networking Sites, Literacy, and the Authentic Identity Problem, TechTrends, 58(2), pp. 93-98.

McKenzie-Mohr, D. (2000), Fostering Sustainable Behaviour Through Community-Based Social Marketing, American Psychologist, $55(5)$, pp. $531-537$.

Naeem, M. (2020). The Role of Social Media to Generate Social Proof as Engaged Society for Stockpiling Behaviour of Customers During Covid-19 Pandemic. An International Journal. https://doi-org.ezaccess.library.uitm.edu.my/10.1108/QMR-04-2020-0050

Nashwan, S. A. and AI-Daihani, M. (2020). Fundraising Campaigns Via Social Media Platforms for Mitigating the Impacts of the COVID-19 Epidemic. Journal of Islamic Marketing. https://doi-org.ezaccess.library.uitm.edu.my/10.1108/JIMA-07-2020-0200

Norsiah A. H. (2020, June 19). Pandemik COVID-19 dan Kebergantungan Kepada Media. Tinta Minda, Bernama. https://www.bernama.com/bm/tintaminda/news.php?id=1851891 
Sekaran, U. and Bougie, R. (2010), Research Methods for Business: A Skill Building Approach, 5th ed., Wiley.

Sumaedi, S. I., Bakti, G. M. Y., Rakhmawati, T., Astrini, N. J., Widianti, T., Damayanti, S., Massijaya, M. A. and Jati, R. K. (2020). A Model of Intention to Use Official COVID-19 Websites. Health Education, 120(4). https://doi-org.ezaccess.library.uitm.edu.my/10.1108/HE-07-2020-0048

Sweldens, S., Corneille, O., and Yzerbyt, V. (2014). The Role of Awareness in Attitude Formation Through Evaluative Conditioning. Personality and Social Psychology Review, 18(2), 187-209. https://doi.org/10.1177/1088868314527832

Wang, Q., Chen, W., \& Liang, Y. (2011). The Effects of Social Media on College Students.

Xie, X. F., Zang, Z. P. and Ponzoa, J. M. (2020). The Information Impact of Network Media, The Psychological Reaction to the COVID-19 Pandemic, and Online Knowledge Acquisition: Evidence from Chinese College Students. Journal of Innovation and Knowledge 5, pp. 297-305.

Zhong, B. L., Luo, W., Li, H. M., Zhang, Q. Q., Liu, X. G., Li, W. T., \& Li, Y. (2020). Knowledge, Attitudes, and Practices Towards CoVID-19 Among Chinese Residents During the Rapid Rise Period of the COVID-19 Outbreak: A Quick Online Cross-Sectional Survey. International Journal Biological Science, 16(10), pp. $1745-1752$. 